\title{
UREDBA (EU) 910/2014 O ELEKTRONSKOJ IDENTIFIKACIJI I USLUGAMA OD POVERENJA ZA ELEKTRONSKE TRANSAKCIJE
}

\begin{abstract}
Jasmina VUKOTIĆ*
Apstrakt: U savremenom svetu, gde su informacione tehnologije i elektronsko poslovanje nezaobilazni, nastala je potreba da se ovo pitanje i pravno reguliše. Pravni okviri su već postavljeni Direktivom 1999/93/EZ i drugim aktima donetim u ovoj oblasti, ali razvoj elektronskog poslovanja nameće stalno prilagođavanje novim potrebama. Kako bi se povećalo poverenje korisnika i efikasnost usluga koje se pružaju u okviru elektronskog poslovanja, bilo je neophodno proširiti postojeći pravni okvir i detaljnije regulisati usluge od poverenja, kao i elektronsku identifikaciju. U radu se analizira Uredba (EU) 910/2014 o elektronskoj identifikaciji i uslugama od poverenja za elektronske transakcije. U Republici Srbiji je po ugledu na ovu Uredbu 2017. godine donet Zakon o elektronskom dokumentu, elektronskoj identifikaciji i uslugama od poverenja u elektronskom poslovanju, te analiza Uredbe ima za cilj i bolje razumevanje odredaba ovog zakona koji je već tri godine u primeni.

Ključne reči: elektronska identifikacija, usluge od poverenja, elektronski potpis, elektronski pečat, elektronski vremenski žig, elektronska dostava, elektronski dokument.
\end{abstract}

\section{1) SVRHA}

Uredba ima za cilj da poveća poverenje u elektronske transakcije na unutrašnjem tržištu pružajući zajedničke osnove za sigurnu elektronsku interakciju između građana, kompanija i javne vlasti, te da poveća efikasnost online usluga i elektronskog poslovanja. Uredbom se proširuju okviri predviđeni u Direktivi 1999/93/EZ, a uvode i nova rešenja u cilju međugraničnog i međusektorskog

\footnotetext{
* Prof dr Jasmina Vukotić, Visoka škola strukovnih studija za informacione tehnologije ITS, Beograd - Zemun, Cara Dušana 34.

E-mail: jasmina1vukotic@gmail.com
} 
povezivanja i uvođenja verodostojnih elektronskih transakcija jednostavnih za korišćenje. Uredbom je uređena elektronska identifikacija u svrhu uklanjanja postojećih prepreka u prekograničnom korišćenju sredstava za elektronsku identifikaciju barem za javne usluge, bez zadiranja u elektronske sisteme upravljanja identitetom i sa njima povezane infrastrukture u državama članicama. Što se tiče usluga od poverenja Uredba ima za cilj da odredi opšti pravni okvir za korišćenje ovih usluga, bez opšte obaveze njihovog korišćenja ili uvođenja pristupne tačke za sve postojeće usluge od poverenja. Ova Uredba ima za cilj da se primenjuje samo na one usluge od poverenja koje se pružaju javnosti i koje imaju dejstvo na treće strane. Regulisanje elektronskih dokumenata je važno zbog daljeg razvoja prekograničnih elektronskih transakcija na unutrašnjem tržištu.

\section{2) MERE EU}

Uredba (EU) br. 910/2014 Evropskog parlamenta i Saveta od 23. jula 2014. godine o elektronskoj identifikaciji i uslugama od poverenja za elektronske transakcije na unutrašnjem tržištu i stavljanju van snage Direktive 1999/93/EZ „Regulation (EU) no 910/2014 of the European Parliament and of the Council of 23 July 2014 on electronic identification and trust services for electronic transactions in the internal market and repealing Directive 1999/93/EC".

\section{3) SADRŽAJ}

Uredba o elektronskoj identifikaciji i uslugama od poverenja je podeljena na šest poglavlja. Prvo poglavlje sadrži opšte odredbe, drugo elektronsku identifikaciju, treće usluge od poverenja, četvrto reguliše elektronske dokumente, peto delegiranje ovlašćenja i odredbe za implementaciju Uredbe i šesto završne odredbe. U ovom radu biće reči o elektronskoj identifikaciji, uslugama od poverenja i o elektronskom dokumentu.

\subsection{ELEKTRONSKA IDENTIFIKACIJA ${ }^{1}$}

Uredba o elektronskoj identifikaciji i uslugama od poverenja za elektronske transakcije reguliše uzajamno priznavanje sredstva elektronske identifikacije koje je izdato u jednoj državi članici za potrebe prekogranične autentikacije, radi pristupa usluzi koju telo javnog sektora druge države članice pruža online. ${ }^{2}$ Da bi

\footnotetext{
${ }^{1}$ Pod elektronskom identifikacijom se podrazumeva postupak korišćenja ličnih identifikacionih podataka u elektronskoj formi, koji na nedvosmislen način predstavljaju fizičko ili pravno lice, ili fizičko lice koje predstavlja pravno lice.

${ }^{2}$ Pod sredstvom elektronske identifikacije se podrazumeva materijalna ili nematerijalna jedinica koja sadrži lične identifikacione podatke i koja se koristi za autentikaciju za online usluge.
} 
se izvršilo uzajamno priznavanje sredstvo elektronske identifikacije mora da bude izdato u okviru šeme elektronske identifikacije koja se nalazi na popisu koji je objavila Komisija, da stepen sigurnosti tog sredstva odgovara ili je viši od stepena sigurnosti koji zahteva nadležno telo javnog sektora radi pristupa toj usluzi online, uz dodatni uslov da stepen sigurnosti tog sredstva odgovara značajnom ili visokom stepenu sigurnosti, te da odgovarajuće telo javnog sektora primenjuju značajan ili visok stepen sigurnosti u odnosu na pristupanje toj usluzi online. ${ }^{3,4}$ Ukoliko su ispunjeni gore navedeni uslovi uzajamno priznavanje mora uslediti najkasnije 12 meseci nakon što Komisija objavi popis.

Ova Uredba u čl. 8 reguliše i bliže uslove koje moraju ispunjavati šeme elektronske identifikacije da bi bile svrstane u odgovarajuću grupu shodno stepenu sigurnosti. Po tom osnovu ona mogu imati nizak, značajan ili visok stepen sigurnosti. Nizak stepen sigurnosti ima ono sredstvo elektronske identifikacije koje pruža ograničen stepen pouzdanja u odnosu na traženi ili utvrđeni identitet osobe, te se odlikuje upućivanjem na tehničke specifikacije, norme i sa njima povezane postupke, uključujući tehničke kontrole čija je svrha smanjenje rizika zloupotrebe ili promene identiteta. Značajan, odnosno visok stepen sigurnosti ima ono sredstvo elektronske identifikacije koje pruža značajan, odnosno viši stepen pouzdanja u odnosu na traženi ili utvrđeni identitet osobe, uz upućivanja na tehničke specifikacije, norme i sa njima povezane postupke, uključujući tehničke kontrole. Komisija određuje minimalne tehničke specifikacije, norme i postupke u odnosu na koje se sredstva elektronske identifikacije svrstavaju u pomenuta tri stepena sigurnosti, koje se određuju upućivanjem na pouzdanost i kvalitet odgovarajućih elemenata (postupak dokazivanja i verifikacije identiteta podnosioca zahteva za izdavanje sredstva elektronske identifikacije, postupak izdavanja traženog sredstva, mehanizam autentikacije lica, tela koja izdaju sredstvo ili su uključena u podnošenje zahteva, tehničke i sigurnosne specifikacije izdatih sredstava).

U čl. 7 Uredbe su navedeni uslovi pod kojima su šeme elektronske identifikacije prihvatljive za prijavu, a u čl. 9 samo prijavljivanje Komisiji. Uslovi za prihvatljivost prijavljivanja su sledeći: da su sredstva elektronske identifikacije izdata od strane države koja vrši prijavljivanje, ili u okviru njenog mandata ili priznata od nje, da se ta sredstva mogu koristiti za pristup bar jednoj usluzi koju pruža telo javnog sektora i koja zahteva elektronsku identifikaciju u državi članici koja vrši prijavljivanje, da šema elektronske identifikacije i sredstvo izdato u okviru nje ispunjavaju bar jedan stepen sigurnosti, da država koja vrši prijavljivanje osigurava da lični identifikacioni podaci

\footnotetext{
${ }^{3}$ Pod šemom elektronske identifikacije podrazumeva se šema u okviru koje se izdaju sredstva elektronske identifikacije fizičkim ili pravnim licima, ili fizičkim licima koja predstavljaju pravna lica.

${ }^{4}$ Telima javnog sektora je ostavljena mogućnost da priznaju i sredstvo elektronske identifikacije niskog stepena sigurnosti, a shodno čl. 6 st. 2 ove Uredbe.
} 
nedvosmisleno predstavljaju fizičko ili pravno lice u vreme izdavanja tog sredstva, te da strana koja izdaje ova sredstva osigurava da se ona pripisuju pomenutom fizičkom ili pravnom licu, da država članica osigurava dostupnost autentikacije online, tako da svaka pouzdajuća strana u drugoj državi članici može potvrditi lične identifikacione podatke u elektronskom obliku i da najmanje šest meseci pre prijave država koja vrši prijavljivanje dostavlja drugoj državi članici opis šeme u skladu sa čl. 12 st. 7 Uredbe, te da šema ispunjava uslove shodno implementirajućem aktu iz čl. 12 st. 8 ove Uredbe. ${ }^{5}$

Shodno čl. 9 država članica Komisiji prijavljuje sledeće informacije i njihove naknadne izmene: opis šeme elektronske identifikacije, uključujući njegove stepene sigurnosti i izdavaoca sredstva elektronske identifikacije, primenljivi sistem nadzora i informacije o pravilima o odgovornosti u odnosu na stranu koja izdaje sredstvo elektronske identifikacije i u odnosu na stranu koja sprovodi postupak autentikacije, odgovorna tela za šeme elektronske identifikacije, informacije o subjektima koji upravljaju registracijom jedinstvenih ličnih identifikacionih podataka, opis načina ispunjavanja zahteva iz implementacijskih akata koja se tiču okvira interoperabilnosti, opis autentikacije i sporazume o suspenziji ili opozivu šeme elektronske identifikacije ili autentikacije ili pojedinih ugroženih delova.

Komisija u roku od godinu dana od dana primene implementirajućih akata koji se odnose na minimalne tehničke specifikacije, norme i postupke za sredstva elektronske identifikacije i na nivo interoperabilnosti, objavljuje popis prijavljenih šema elektronske identifikacije i osnovne informacije o njima. Ukoliko se podnesu naknadne prijave Komisija objavljuje izmenu popisa u roku od dva meseca od prijema zahteva. Ukoliko država članica podnese zahtev za uklanjanje prijavljene šeme, objava izmene popisa vrši se u roku od mesec dana od prijema takvog zahteva.

U slučaju povrede ili delimičnog ugrožavanja šeme elektronske identifikacije ili autentikacije država koja je izvršila prijavljivanje bez odlaganja suspenduje ili opoziva tu prekograničnu autentikaciju ili ugrožene delove, o čemu obaveštava ostale države članice i Komisiju. Ako se povreda ili ugrožavanje ukloni onda država koja je izvršila prijavljivanje ponovo uspostavlja prekograničnu autentikaciju, o čemu bez odlaganja obaveštava ostale države članice i Komisiju. Međutim, ukoliko u roku od tri meseca od suspenzije ili opoziva povreda ili ugrožavanje ne budu uklonjeni, država koja je izvršila prijavljivanje obaveštava o povlačenju šeme elektronske identifikacije ostale države članice i Komisiju. U pomenutim slučajevima Komisija objavljuje odgovarajuće izmene popisa.

${ }^{5} \mathrm{U}$ čl. 12 Uredbe je regulisana saradnja (u pogledu čega države sarađuju i u čemu se sastoji ta saradnja) i interoperabilnost jer nacionalne šeme elektronske identifikacije moraju biti interoperabilne, te je u tom cilju uspostavljen okvir za interoperabilnost, kriterijumi koje on mora ispunjavati i njegov sastav. Shodno st. 7 ovog člana Komisija je bila dužna da implementirajućim aktima do 18. marta 2015. godine uspostavi potrebne postupajuće aranžmane kako bi se olakšala saradnja između država članica, a shodno st. 8 do istog datuma da donese implementirajuće akte o okviru za interoperabilnost. 
Uredba predviđa i odgovornost za štetu prouzrokovanu namerno ili nepažnjom svakom fizičkom ili pravnom licu pri prekograničnoj transakciji kako države članice koja vrši prijavljivanje tako i strane koja izdaje sredstva elektronske identifikacije i strane koja sprovodi postupak autentikacije koja je prouzrokovana nepoštovanjem obaveza, čime se ne dovodi u pitanje odgovornost prema nacionalnom pravu stranaka transakcije.

\subsection{USLUGE OD POVERENJA}

U pogledu usluga od poverenja Uredba sadrži opšte odredbe (koje se tiču odgovornosti za štetu, položaj pružalaca usluga od poverenja sa sedištem u trećoj zemlji, dostupnost usluga osobama sa invaliditetom i sankcije za nepoštovanje odredaba ove Uredbe), odredbe koje se odnose na nadzor, na kvalifikovane usluge od poverenja uopšte i na pojedine usluge od poverenja (elektronski potpisi, elektronski pečati, elektronski vremenski žigovi, usluge elektronske preporučene dostave i autentikacije veb-sajtova).

Države članice određuju nadzorno telo koje je odgovorno za poslove nadzora u onoj državi članici koja ga određuje, o čemu obaveštavaju Komisiju i druge države članice. Nadzorno telo nadzire preventivno i naknadno kvalifikovane pružaoce usluga od poverenja sa sedištem na teritoriji države članice koja ga određuje i po potrebi preduzima mere protiv pružalaca nekvalifikovanih usluga od poverenja putem naknadnih aktivnosti nadzora. U cilju vršenja svoje uloge nadzorna tela vrše saradnju sa drugim nadzornim telima, telima za zaštitu podataka o ličnosti, podnose izveštaje Komisiji, dodeljuju i ukidaju status kvalifikovanim pružaocima usluga od poverenja i uslugama koje oni pružaju i sl. Nadzorna tela u različitim državama članicama međusobno sarađuju u cilju razmenjivanja dobre prakse.

Uredba dalje reguliše bezbedonosne uslove koji se tiču pružaoca usluga od poverenja. Kako kvalifikovani, tako i nekvalifikovani pružaoci usluga od poverenja preduzimaju odgovarajuće tehničke i organizacione mere za upravljanje rizicima koji prete bezbednosti usluga koje oni pružaju. Imajući u vidu najnovija tehnološka dostignuća ovim merama se obezbeđuje da stepen bezbednosti odgovora stepenu rizika, a posebno se preduzimaju mere za sprečavanje i smanjivanje bezbednosnih incidenata, te za obaveštavanje učesnika o neželjenim efektima tih incidenata. Obaveza obaveštavanja se odnosi na nadzorno telo, kao i druga tela u slučaju potrebe, i to o svakoj povredi bezbednosti ili gubitku celovitosti koji imaju značajan uticaj na pruženu uslugu od poverenja ili podatke o ličnosti koji su u njoj sadržani. Ovo obaveštavanje se vrši bez odlaganja, a najkasnije u roku od 24 sata od saznanja. Ako postoji mogućnost da ove povrede mogu nepovoljno uticati na fizičko ili pravno lice kojima su pružene usluge od poverenja, onda se vrši obaveštavanje ovih lica. Takođe, u slučaju potrebe obaveštava se nadzorno telo i neke druge države članice, kao i javnost, a to čini nadzorno telo konkretne države članice u kojoj se takva povreda dogodila. 
Što se tiče kvalifikovanih usluga od poverenja uopšte, najpre je regulisan nadzor nad pružaocima ovih usluga tako što telo koje ocenjuje usklađenost pružalaca i usluga koje oni pružaju sa odredbama ove Uredbe (nadzorno telo o kome je bilo reči ili neko posebno telo koje obavlja te poslove) obavlja reviziju pružalaca kvalifikovanih usluga od poverenja o njihovom trošku najmanje svaka 24 meseca. Kvalifikovani pružaoci usluga od poverenja o izvršenoj reviziji podnose izveštaj nadzornom telu u roku od tri dana od njegovog prijema (u slučaju da reviziju vrši posebno telo, a ne samo nadzorno telo). Pored redovne revizije nadzorno telo može obaviti ili zahtevati od posebnog tela da obavi ovu reviziju u svakom trenutku kako bi potvrdilo da kvalifikovani pružaoci usluga i usluge koje oni pružaju ispunjavaju zahteve utvrđene u Uredbi. Ukoliko se čini da je došlo do povrede podataka o ličnosti o rezultatima revizije obaveštava se nadležno telo za zaštitu podataka o ličnosti. Ukoliko se utvrdi da kvalifikovani pružalac usluga ili usluga koju ono pruža ne ispunjava neki zahtev iz Uredbe, nadzorno telo zahteva da on te nedostatke otkloni, a ukoliko ne preduzme mere i ne postupi po zahtevu, nadzorno telo može ukinuti njegov status kvalifikovanog pružaoca usluga od poverenja ili kvalifikovani status neke od usluga koje on pruža, pri čemu posebno uzima u obzir obim, trajanje i posledice nepoštovanja.

Kada neki pružalac usluga od poverenja želi da stekne status kvalifikovanog pružaoca usluga od poverenja on podnosi prijavu nadzornom telu, zajedno sa izveštajem o ocenjivanju usklađenosti. Nakon provere da li pružalac usluga ispunjava zahteve iz Uredbe za kvalifikovanog pružaoca i za kvalifikovane usluge od poverenja, nadzorno telo daje kvalifikovani status pružaocu usluga od poverenja i uslugama koje pruža i o tome obaveštava telo koje vodi pouzdane popise ovakvih pružalaca usluga i usluga koje oni pružaju, u roku od tri meseca od prijave. Kvalifikovani pružaoci usluga od poverenja mogu započeti obavljanje ovih poslova tek nakon što njihov kvalifikovani status bude naznačen na pouzdanim popisima.

Obaveza je svake države članice da izrađuje, vodi, objavljuje i odgovara za pouzdane popise koji sadrže informacije o kvalifikovanim pružaocima usluga od poverenja i o kvalifikovanim uslugama od poverenja. Države članice obaveštavaju Komisiju o ovom telu i detaljima gde se popisi objavljuju, kako i slično, a Komisija ove informacije stavlja na uvid javnosti. Nakon što na popisu bude naznačen status kvalifikovanog pružaoca usluga od poverenja, takav pružalac može da koristi EU znak pouzdanosti, kako bi naznačio kvalifikovane usluge od poverenja koje pruža.

Dalje, Uredba u čl. 24 reguliše zahteve u vezi sa kvalifikovanim pružaocima usluga od poverenja, tj. njihove obaveze. Kvalifikovani pružalac usluga od poverenja je obavezan da pre izdavanja kvalifikovanog sertifikata za uslugu od poverenja utvrdi identitet $\mathrm{i}$ ako je to primenljivo i posebna obeležja fizičkog ili pravnog lica kojima taj sertifikat izdaje. ${ }^{6}$ Takođe, kvalifikovani pružalac usluga od poverenja je

\footnotetext{
${ }^{6}$ Identitet proverava ili sam pružalac usluga od poverenja ili oslanjajući se na neko treće lice, a u skladu sa drugim podstavom stava 1. člana 24 Uredbe.
} 
dužan da obaveštava nadzorno telo o svakoj promeni u vezi sa pružanjem usluga i o nameri prestanka te delatnosti, da zapošljava lica koja imaju potrebno stručno znanje, pouzdanost, iskustvo i kvalifikacije i koja su prošla odgovarajuće osposobljavanje, da poseduje odgovarajuća finansijska sredstva u pogledu rizika od odgovornosti za štetu, da pre stupanja u ugovorni odnos obaveštava svako lice koje želi da koristi uslugu o uslovima njenog korišćenja, da koristi verodostojne sisteme i proizvode i obezbeđuje tehničku sigurnost i pouzdanost postupaka koje ti sistemi i proizvodi koriste, da koristi verodostojne sisteme za čuvanje dostavljenih podataka, da preduzima odgovarajuće mere protiv falsifikovanja i krađe podataka, da beleži i čini dostupnim sve bitne informacije u vezi sa podacima koje izdaje i prima, da ima ažuriran plan prekida pružanja usluge, da poštuje odredbe o zaštiti podataka o ličnosti, te da ako izdaje kvalifikovane sertifikate uspostavlja i ažurira bazu podataka sertifikata. Ako kvalifikovani pružalac usluga od poverenja koji izdaje kvalifikovane sertifikate odluči da opozove sertifikat, on to mora registrovati u svojoj bazi podataka i pravovremeno (u svakom slučaju unutar 24 sata od prijema zahteva) objaviti status opoziva sertifikata. U vezi sa kvalifikovanih sertifikatima pružaoci usluga pružaju bilo kojoj pouzdajućoj strani informacije o statusu validnosti ili opoziva sertifikata koje su izdali.

\subsection{ELEKTRONSKI POTPISI I ELEKTRONSKI PEČATI}

Uredba najpre propisuje da se elektronskom dokazu, kao dokazu u sudskom postupku, ne sme uskratiti pravno dejstvo i dopuštenost samo zato što je u elektronskom obliku ili zato što ne ispunjava sve zahteve za kvalifikovani elektronski potpis. Kvalifikovanom elektronskom potpisu priznaje se isto pravno dejstvo kao svojeručnom potpisu, a kvalifikovani elektronski potpis koji se zasniva na kvalifikovanom sertifikatu izdatom u jednoj državi članici priznaje se kao takav u svim ostalim državama članicama. Uredba, dalje, reguliše zahteve koje treba da ispuni napredni elektronski potpis: da je na nedvosmislen način povezan sa potpisnikom, da omogućava identifikaciju potpisnika, da je izrađen korišćenjem podataka za izradu elektronskog potpisa koje potpisnik može, uz visok stepen poverenja, koristiti pod svojom isključivom kontrolom i da je povezan sa njim potpisanim podacima na način da se može otkriti bilo kakva naknadna izmena podataka. ${ }^{7,8}$

\footnotetext{
${ }^{7}$ Komisija može utvrditi referentne brojeve standarda za napredne elektronske potpise, kojima se zamenjuju propisani zahtevi, a obavezna je da utvrdi referentne formate naprednih elektronskih potpisa ili referentne metode ako se koriste alternativni formati. 0 ovome bliže: čl. 27, st. 4 i 5 Uredbe.

${ }^{8}$ Kada neka država zahteva napredni elektronski potpis za korišćenje neke online javne usluge, ta država članica priznaje napredne elektronske potpise, napredne elektronske potpise koji se zasnivaju na kvalifikovanom sertifikatu za elektronske potpise i kvalifikovane elektronske potpise. A ako neka država za pristup ovim uslugama zahteva napredni elektronski potpis koji
} 
Što se tiče kvalifikovanih sertifikata za elektronske potpise oni moraju da ispune samo uslove (ne i dodatne obavezne uslove) predviđene u aneksu I Uredbe: naznaku da je sertifikat izdat kao kvalifikovani sertifikat za elektronske potpise, skup podataka koji nedvosmisleno predstavlja kvalifikovanog pružaoca usluga od poverenja, barem ime potpisnika, podatke za validaciju elektronskog potpisa koji odgovaraju podacima za izradu elektronskog potpisa, podatke o početku i kraju roka važnosti sertifikata, oznaku sertifikata, napredan elektronski potpis ili pečat kvalifikovanog pružaoca usluga od poverenja koji izdaje sertifikat i mestu gde je dostupan sertifikat koji podržava taj potpis odnosno pečat, mestu usluge koja se može koristiti za ispitivanje statusa valjanosti kvalifikovanog sertifikata, te ako su podaci za izradu elektronskog potpisa smešteni u kvalifikovanom sredstvu za izradu elektronskog potpisa oznaku istog. Kvalifikovani sertifikati za elektronske potpise mogu sadržati dodatna posebna obeležja koja nisu obavezna. Ako se sertifikat opozove nakon aktivacije on gubi valjanost od trenutka opoziva i njegov status se ne može vratiti u pređašnje stanje. Države članice mogu utvrditi pravila za suspenziju ovih sertifikata po uslovom da je u pitanju privremena suspenzija tokom koje on gubi valjanost $i$ da je to period suspenzije naznačen u bazi podataka i vidljiv iz usluge u okviru koje se pružaju informacije o statusu sertifikata. Komisiji je ostavljena mogućnost da utvrdi referentne brojeve standarda za kvalifikovane sertifikate, te ako sertifikat odgovara tim standardima smatra se da su ispunjeni uslovi iz aneksa I.

Uredba takođe predviđa koje uslove treba da ispune kvalifikovana sredstva za izradu elektronskih potpisa, kao i mogućnost da Komisija utvrdi referentne brojeve standarda koji mogu zameniti te uslove. ${ }^{9}$ Saglasnost kvalifikovanih sredstava za izradu elektronskih potpisa sa predviđenim uslovima potvrđuju odgovarajuća javna ili privatna tela koja određuju države članice, o čemu one obaveštavaju Komisiju, koja na osnovu ovih informacija izrađuje, objavljuje i vodi popis sertifikovanih sredstava za izradu elektronskog potpisa. Pomenuta sertifikacija se zasniva ili na

se zasniva na kvalifikovanom sertifikatu, ta država priznaje napredne elektronske potpise koji se zasnivaju na kvalifikovanom sertifikatu za elektronske potpise i kvalifikovane elektronske potpise. 0 ovome bliže: čl. 27 st. 1-3 Uredbe.

${ }^{9} \mathrm{U}$ aneksu II Uredbe navedeni su uslovi koje moraju ispuniti kvalifikovana sredstva za izradu elektronskog potpisa: ona moraju pomoću odgovarajućih tehničkih i proceduralnih sredstava obezbeđivati poverljivost podataka za izradu elektronskog potpisa, da se podaci za izradu mogu pojaviti samo jednom, da se podaci za izradu elektronskog potpisa ne mogu izvesti iz njega, da je elektronski potpis zaštićen od falsifikovanja i da zakoniti potpisnik može pouzdano zaštiti podatke za njegovu izradu od korišćenja od strane drugih lica. Dalje, kvalifikovana sredstva za izradu elektronskog potpisa ne smeju menjati podatke koji se potpisuju ili sprečavati da ti podaci budu vidljivi potpisniku pre potpisivanja. Generisanje ili upravljanje podacima u ime potpisnika može da obavlja isključivo kvalifikovani pružalac usluga od poverenja, koji pod određenim uslovima može praviti duplikate podataka isključivo za svrhu povraćaja podataka. 
postupku sigurnosne evaluacije u skladu sa jednim od standarda za ocenu sigurnosti proizvoda informacione tehnologije (Komisija utvrđuje popis standarda za ocenu sigurnosti tih proizvoda), ili drugačijem postupku pod uslovom da taj postupak koristi uporedive sigurnosne stepene i da Komisija bude obaveštena o tom postupku (koji se primenjuje u slučaju nepostojanja sigurnosnih standarda ili ako je u toku postupak sigurnosne evaluacije). ${ }^{10}$

Valjanost kvalifikovanog elektronskog potpisa utvrđuje se postupkom validacije tog potpisa, a isti je valjan ako je sertifikat koji ga podržava u trenutku potpisivanja bio kvalifikovani sertifikat za elektronske potpise, ako je taj sertifikat izdao kvalifikovani pružalac usluga od poverenja i on bio valjan u trenutku potpisivanja, ako podaci za validaciju potpisa odgovaraju podacima koji se pružaju pouzdajućoj strani i ako je toj strani ispravno dostavljen jedinstveni skup podataka koji predstavlja potpisnika u sertifikatu, te joj jasno naznačeno korišćenje pseudonima, ako je elektronski potpis izrađen sredstvom za izradu kvalifikovanog elektronskog potpisa, integritet potpisanih podataka nije bio ugrožen i ako su bili ispunjeni uslovi koji se traže za napredne elektronske potpise. Takođe, Komisija može utvrditi referentne brojeve standarda za validaciju kvalifikovanih elektronskih potpisa, koji zamenjuju gore navedene zahteve koji moraju biti ispunjeni da bi kvalifikovani elektronski potpis bio validiran. Sistem koji se koristi za validaciju obezbeđuje pouzdajućoj strani tačan rezultat postupka validacije i omogućava joj otkrivanje svakog problema vezanog za bezbednost.

Uredba reguliše kao uslugu od poverenja i kvalifikovanu uslugu validacije kvalifikovanih elektronskih potpisa koju može da vrši samo kvalifikovani pružalac usluga od poverenja, koji pruža validaciju u skladu sa gore navedenih zahtevima i koji omogućava pouzdajućim stranama primanje rezultata validacije na automatski način, koji je pouzdan, efikasan i potpisan kvalifikovanim elektronskim potpisom ili pečatom kvalifikovanog pružaoca te usluge. Takođe, Komisija može da utvrdi referentne brojeve standarda za kvalifikovanu uslugu validacije, koji zamenjuju prethodno tražene zahteve. Pored ove usluge, a u vezi sa elektronskim potpisima regulisana je i kvalifikovana usluga čuvanja kvalifikovanih elektronskih potpisa, koju može da pruža samo kvalifikovani pružalac usluga od poverenja koji koristi postupke i tehnologije koje mogu produžiti pouzdanost kvalifikovanog elektronskog potpisa na period koji je duži od perioda tehnološke valjanosti. ${ }^{11}$

Uredba kao usluge od poverenja prepoznaje i usluge koje se odnose na elektronske pečate: izrada elektronskog pečata, validacija i čuvanje elektronskih pečata. U odnosu na elektronske pečate Uredba sadrži odredbe slične odredbama koje se odnose na elektronski potpis kada uređuje pravno dejstvo elektronskih

${ }^{10}$ Vidi bliže: čl. 30 Uredbe.

${ }^{11}$ Komisija može i u ovom slučaju odrediti referentne brojeve standarda za kvalifikovanu uslugu čuvanja kvalifikovanih elektronskih potpisa, koji standardi zamenjuju propisane zahteve za tu uslugu. 
pečata, zahteve za napredni elektronski pečat, elektronske pečate $u$ javnim uslugama, kvalifikovane sertifikate za elektronske pečate, kvalifikovana sredstva za izradu elektronskog pečata i validaciju i čuvanje kvalifikovanih elektronskih pečata. ${ }^{12}$

\subsection{ELEKTRONSKI VREMENSKI ŽIGOVI, USLUGA ELEKTRONSKE PREPORUČENE DOSTAVE I USLUGA AUTENTIKACIJE VEB-SAJTOVA}

Kao i kod elektronskog potpisa i elektronskog pečata Uredba reguliše najpre pravno dejstvo elektronskih vremenskih žigova, tako što navodi da se elektronskom vremenskom žigu kao dokazu u sudskom postupku ne sme uskratiti pravno dejstvo i dopuštenost samo zato što je u elektronskom obliku ili zbog toga što ne ispunjava uslove za kvalifikovani elektronski žig. Za kvalifikovani elektronski žig važi pretpostavka tačnosti datuma i vremena koje pokazuje i integritet podataka sa kojima su datum i vreme povezani. Kvalifikovani elektronski vremenski žig izdat u jednoj državi članici priznaje se kao takav u svim državama članicama.

Uredba predviđa da zahteve koje mora ispuniti kvalifikovani vremenski žig, s tim što Komisija, kao i kod ostalih usluga od poverenja, može utvrditi referentne brojeve standarda za povezivanje datuma i vremena sa podacima i za izvore tačnog vremena koji zamenjuju ove zahteve. Ti zahtevi su sledeći: da žig povezuje datum i vreme sa podacima na način kojim se u razumnoj meri isključuje mogućnost neopažene promene podataka, da se zasniva na izvoru tačnog vremena povezanog sa koordiniranim univerzalnim vremenom i da je potpisan naprednim elektronskim potpisom ili pečatiran naprednim elektronskim pečatom kvalifikovanog pružaoca usluga od poverenja ili nekom ekvivalentnom metodom.

Što se tiče usluge elektronske preporučene dostave Uredba predviđa da se podacima poslatim i primljenim korišćenjem ove usluge ne sme uskratiti pravno dejstvo i dopuštenost kao dokaza u sudskim postupcima samo zbog svog oblika ili zbog toga što ne ispunjavaju sve zahteve za kvalifikovane usluge elektronske preporučene dostave. Za podatke poslate i primljene upotrebom kvalifikovane usluge elektronske preporučene dostave podrazumeva se integritet podataka, slanje tih podataka od strane identifikovanog pošiljaoca, njihov prijem od strane identifikovanog primaoca, te tačnost datuma i vremena slanja i prijema podataka kako su označeni kvalifikovanom uslugom elektronske preporučene dostave.

Kvalifikovane usluge elektronske preporučene dostave moraju ispunjavati određene zahteve: da ih pruža jedan ili više kvalifikovanih pružalaca usluga od poverenja, da uz visok stepen poverenja obezbeđuju indentifikaciju pošiljaoca, da

${ }^{12} 0$ elektronskim pečatima videti bliže: čl. 35-40 i aneks III Uredbe. Što se tiče pravnog dejstva elektronskog pečata treba napomenuti da se za kvalifikovani elektronski pečat pretpostavlja integritet podataka i tačnost izvora podataka sa kojima je kvalifikovani elektronski pečat povezan. 
obezbeđuju identifikaciju primaoca pre dostave podataka, da je slanje ili primanje podataka obezbeđeno naprednim elektronskim potpisom ili pečatom kvalifikovanog pružaoca usluga od poverenja na način kojim se isključuje mogućnost neopažene promene podataka, da se pošiljaocu i primaocu podataka jasno označava svaka promena podataka potrebna radi njihovog slanja ili prijema i da se datum i vreme slanja, primanja i eventualne promene podataka označava kvalifikovanim elektronskim vremenskim žigom. Ovi zahtevi se primenjuju i u slučaju prenosa podataka između više kvalifikovanih pružalaca usluga od poverenja, a Komisija može utvrditi referentne brojeve standarda za postupke slanja i prijema podataka, kojim zamenjuju gore tražene zahteve.

Uredba predviđa i uslugu autentikacije veb-sajtova, ali ne sadrži opšte odredbe o tome, već samo zahteve za kvalifikovane sertifikate za autentikaciju veb-sajtova, kao i mogućnost da za njih Komisija utvrdi referentne brojeve standarda, koji zamenjuju tražene zahteve. U aneksu IV Uredbe navedeni su sledeći zahtevi za kvalifikovane sertifikate za autentikaciju veb-sajtova: naznaku da se radi o kvalifikovanom sertifikatu, skup podataka koji nedvosmisleno predstavljaju kvalifikovanog pružaoca usluga poverenja koji izdaje ove sertifikate, barem ime ili naziv fizičkog ili pravnog lica kome je izdat sertifikat i elemente njihove adrese, nazive domena kojima upravlja lice kome je izdat sertifikat, podatke o početku i kraju važnosti sertifikata, identifikacijsku oznaku sertifikata, napredan elektronski potpis ili pečat kvalifikovanog pružaoca usluge od poverenja koji izdaje sertifikat i mesto gde je dostupan sertifikat koji podržava taj potpis, odnosno pečat i mesto usluga statusa valjanosti sertifikata. ${ }^{13}$

\subsection{ELEKTRONSKI DOKUMENTI}

Što se tiče elektronskog dokumenta Uredba sadrži samo odredbu o njegovom pravnom dejstvu i predviđa da se ovom dokumentu kao dokazu u sudskim postupcima ne sme uskratiti pravno dejstvo i dopuštenost samo zato što je on u elektronskom obliku.

\section{4) DATUM STUPANJA NA SNAGU}

Uredba stupa na snagu dvadesetog dana od dana objavljivanja u Službenom listu Evropske unije, a primenjuje se od 1. jula 2016. godine, izuzev pojedinih odredaba za koje je predviđeno da se primenjuju od 17. septembra 2014. godine, odnosno od dana primene implementirajućih akata ili tri godine od dana njihove primene. ${ }^{14}$

\footnotetext{
${ }^{13}$ Vidi aneks IV Uredbe.

${ }^{14}$ Vidi čl. 52 st. 2 Uredbe.
} 


\section{5) ZNAČAJ ZA REPUBLIKU SRBIJU}

Materija elektronske identifikacije, usluga od poverenja i elektronskog dokumenta je u Republici Srbiji uređena Zakonom o elektronskom dokumentu, elektronskoj identifikaciji i uslugama od poverenja u elektronskom poslovanju („Službeni glasnik RS”, br. 94/2017) - ZEDEIUPEP. Pomenuti zakon reguliše sva tri bitna pitanja koja reguliše i Uredba, s tim što je redosled njihove obrade drugačiji. U ZEDEIUPEP se najpre reguliše elektronski dokument i to šire nego u Uredbi, zatim se reguliše elektronska identifikacija i na kraju usluge od poverenja. Odredbe ZEDEIUPEP o elektronskoj identifikaciji prate odredbe Uredbe u tom delu, a što se tiče usluga od poverenja ovaj zakon reguliše najpre opšte uslove za sve kvalifikovane usluge od poverenja, a zatim pojedinačne usluge od poverenja. Vrste i broj usluga od poverenja su identični vrstama i broju usluga od poverenja navedenih u Uredbi.

Iz navedenog može se zaključiti da je ZEDEIUPEP donet nakon Uredbe i da se oslanja na rešenja primenjena u Uredbi, s tom razlikom što u delu koji se odnosi na elektronski dokument sadrži podrobnije odredbe koje se odnose na njegovu izradu, forme prikaza, original i kopiju elektronskog dokumenta. ZEDEIUPEP je stupanjem na snagu stavio van snage Zakon o elektronskom dokumentu iz 2009. godine i Zakon o elektronskom potpisu iz 2004. godine, a pored ova dva pitanja regulisao je i pitanje elektronske identifikacije koje ranije nije bilo uređeno.

\section{REGULATION (EU) 910/2014 ON ELECTRONIC IDENTIFICATION AND TRUST SERVICES FOR ELECTRONIC TRANSACTIONS}

Summary: In the modern world, information technologies and electronic business are unavoidable parts of our lives, and therefore it is necessary to regulate these issues. The legal framework is already set by Directive 1999/93/EC and other acts enacted in this area, but the development of e-business requires constant adaptation to the new needs. In order to increase the trust of users and the efficiency of services provided within the e-business, it was necessary to expand the existing legal framework and regulate in detail the trust services, as well as electronic identification. This paper analyses Regulation (EU) 910/2014 on electronic identification and trusted services for electronic transactions. In the Republic of Serbia, following provisions of this Regulation, the Law on Electronic Document, Electronic Identification and Trust Services in Electronic Business was passed in 2017, and the analysis of the Regulation aims to give a better understanding of the provisions of this law, which has been in force for three years. Keywords: electronic identification, trust services, electronic signature, electronic seal, electronic time stamp, electronic delivery services, electronic document. 